\title{
Características de las víctimas del maltrato entre iguales percibidas por adolescentes victimizados y no victimizados
}

\author{
Ana Almeida ${ }^{1}$, \\ María Jesús Caurcel $^{2}$ \\ $\mathrm{y}$ \\ José Cunha Machado ${ }^{1}$
}
${ }^{1}$ Instituto de Estudos da Criança,
Universidade do Minho, Braga
${ }^{2}$ Universidad de Granada

\section{Portugal \\ $\mathbf{y}$ \\ España}

aalmeida@iec.uminho.pt 


\section{Resumen}

Este estudio investiga las características de las víctimas del maltrato entre iguales percibidas por 1237 adolescentes (media de edad es 13.3 años) de dos ciudades del sur de Europa. El principal objetivo fue inspeccionar cómo las descripciones de las víctimas varían en función del país, edad, sexo, estatus de victimización (agresor, víctima y espectador) y la experiencia de los participantes en situaciones de maltrato entre iguales. Los resultados muestran que la percepción de las víctimas como vulnerables se acentúa conforme aumenta la edad de los adolescentes y que los chicos comparados con las chicas tienen una actitud más crítica hacia las víctimas. Los participantes agresores son los que describen a la víctima más desfavorablemente y la perciben como más vulnerable, mientras que los espectadores y el resto de adolescentes que tienen experiencia como víctima o son victimizados tienen percepciones menos estereotipadas y le otorgan atributos más deseables socialmente. Los resultados fueron discutidos en términos de sus implicaciones de cara a la investigación e intervención.

PALABRAS CLAVE: maltrato entre iguales, perfil de víctima, adolescentes

\section{Abstract}

This study investigates perceived characteristics of victims of peer bullying in a sample of 1237 adolescents (mean age is 13.3 years-old) in two southern European countries. Focusing upon perceived characteristics of victimized peers, the main goal was to inspect how descriptions of the victims varied according to country, age, gender, victimization status (whether aggressor, bystander or victim) and self-reported experience as participant in bullying interactions. Results showed that the perceived vulnerability of the victims is accentuated as adolescents grow older and that boys as compared to girls take a more critical attitude towards victims. Aggressors describe the victim less favourably and with greater vulnerability, while bystanders and other adolescents who have experience as a victim or are currently peer-rated as victims hold less stereotyped perceptions and they assign the victims more socially desirable attributes. Findings are discussed in terms of their implications for research and intervention.

KEYWORDS: peer victimization, victim profile, adolescents 


\section{Introduction}

Peer relations play an important role in personal and social adjustment, particularly in childhood and adolescent years (Hartup, 1983; Laursen, 2005; Rubin, Bukowski \& Parker, 1998, Sullivan, 1953). Yet, if throughout the school years having friends and rubbing elbows with a bunch of youngsters about the same age give access to new social worlds and foster children's social selves, relationships are not always enjoyable or free of hassles, and not all children experience a sense of belongingness among their classmates. Moreover, it is argued that the stable nature of peer groups does not always lead to camaraderie or the emergence of friendships; on the contrary, it can perpetuate and even aggravate poor peer relations (Salmivalli, 2001). Difficulties in fitting in with one's peer group and troubled relationships can be grounds for unhappiness and a long line of frustrated expectations about selfperceived social competence and group membership.

In addition, poor peer relations have been well-documented in terms of the development of psychopathology (Alsaker \& Olweus, 1992; Olweus, 1993; Rubin et al., 1998), and a number of studies have emphasized how detrimental they can be for group cohesion, affective communication and interpersonal attitudes among classmates (De Rosier, Cillessen, Coie \& Dodge, 1994; Pepler, Craig \& O’Connell, 1996; Perry, Willard \& Perry, 1990). Peer bullying, whether a cause or a consequence of poor social relationships, entails negative effects for both the individual and the peer group and, given its origin and perpetuation in a social context, it is not plausible to understand and explain the bullying phenomenon outside a relationship perspective (Pepler \& Craig, 2006).

A relationship perspective is an integrative framework and puts forward an interesting research agenda. Until now, the bulk of empirical studies have mainly focused on the development of behavioural, cognitive and emotional patterns of aggressive, victimized or passive-aggressive children, or they have taken a peer group view, substantiated in a view of its structural organization and role differentiation of group members (Salmivalli, Lagerspetz, Björkqvist, Österman \& Kaukiainen,1996; Salmivalli, 2001). The focus here has been in exploring how processes and group mechanisms contribute to the development of bullying. While personality and systemic approaches have echoed the principal contrasting conceptualizations about the phenomenon of bullying, more recently, the relationship 
perspective has considered how individuals actively participate in the processes of constructing social experience. This co-construction process is embedded in collective interactions facilitating thoughts, symbolic representations, meaning attribution, communication, organizing behaviour and setting shared expectations about each other's behaviour.

In the child development domain, these ideas have arisen from theories of the self and symbolic interactionism (Baldwin, 1906; Mead, 1925, 1934), from constructs such as the internal working model (Bretherton \& Munholland, 1999) and also from modern interactive models of socioemotional development (Carlson, Sroufe, Egeland, 2004). Complementary representations of self and others' experience have long been investigated in the social psychological tradition. According to Moscovici (1981) knowledge is socially elaborated and collectively shared (common sense). Such knowledge refers not only to a given reality, as it also is involved in the construction of such reality. Such a construction shapes what is perceived as common sense knowledge. It appeals to certain shared ideas, thoughts, and images about particular realities (natural or sociocultural) which, due to their social fabrication, are embodied with an intense feeling of logical necessity. Besides, social representations are important guides for behaviour and anticipated precursors of action and outcomes. In this respect, it is agreed that neither does representation dispense experience, nor does experience acquire meaning and functionality apart from cognition.

If indeed these interactional and relationship stances are suggestive and allow us to gain a process view of the bullying phenomenon and, in general, of relationship development, this line of research demands further development. In favour of this argument, it has been claimed by different authors that it may not be the children's behaviour per se that maintains their victimization status (Kochendorfer-Ladd, 2003; Vaillancourt, McDougall, Hymel \& Welch, 2001; Boivin, Hymel \& Hodges, 2001). Alternatively, social interactions, relationship experiences and representational processes of reciprocal roles are contributing to the development of bullying behaviors. And, even though victims of peer aggression differ from nonvictims in a number of ways, it is often misleading to attribute the victim's vulnerability to physical strength (Olweus, 1978), disability (Naylor, Granizo, Tantam \& Deurzen, 2005), race or ethnicity, sex or religious orientation (Mellor, 1999; Rivers, 2001; Siann, Callaghan, Glissov, Lockhart, \& Rawson, 1994), to mental disabilities 
(Tattum, 1989), or to special education needs (Tattum, 1997). But it would be an equal fallacy to expect that the quality of relations or social environments affect every child in the exact same way. As Boivin, Hymel \& Hodges (2001) mention, to be rejected or socially withdrawn at school does not necessarily trap children in a dysfunctional pathway or peer victimization. Maybe Ortega y Gasset (1935/2005) put it more clearly when he stated that "man is himself and his circumstance", acknowledging that any predictor of social adjustment must consider the mutual, dynamic influence of individual, representational selfexperience and contextual factors. Developmentally, it is also conceivable that children's self-representations take on a more influential expression in behaviour, whether this is translated into positive outcomes or not. However, in transitional periods, specifically, through adolescence, when adaptation becomes a highly taxing developmental task, a perceived vulnerability can weaken the adolescent's expectations about his or her peer relationships. Unfortunately, many victims' real life and vivid reports attest to that.

Still, taking into consideration that vulnerability is an interactional process, it is considered important to investigate how and why behavioral and nonbehavioral characteristics are associated with bully-victim experiences, without forgetting that specific negative outcomes for the victims of peer bullying (e.g., social reputations) are affected by the identity of the perceiver and severity of the victimization. Negative social reputations especially affect the social status and self-perceptions of children and adolescents. Hymel, Wagner \& Butler (1990) have indicated how the effects of difficult relationships become meaningful and pernicious to one's perceived social competence in the transition from childhood to adolescence. As such, we hypothesized that individual attributes, in order to become risk factors or predispositions to being bullied (or to bully), ought to acquire social meaning and, consequently, be internalized as social categories that differentiate members in a group. In social psychology terms, categorization processes, including interpersonal differentiation, are sociocognitive operations that result in entity construction such as personal and social identities. Therefore, individual differences and, concomitantly, group boundaries represent such social constructions and simultaneously anchor and strength self and social identities (Tajfel, 1978).

At this point, combining the two levels of explanation could present a stimulating challenge. Developmentally, it is conceivable to assert that self-representations of

\footnotetext{
${ }^{1}$ Paraphrasing the philosophical thought of José Ortega y Gasset (1883-1955): "yo soy yo y mi circunstancia".
} 
interpersonal experience will gain relevance in organizing cognitions, emotions and behaviours. Taking a group or societal perspective, it is likely that shared social representations will strengthen maintenance of a multitude of stereotyped perceptions about the individuals in and out of the group of belonging. The result of categorization processes, stereotypes might simultaneously have self- and group-serving purposes, but it is doubtful that these purposes will be beneficial to interpersonal relations.

In the present study, we have three main goals. The first goal is to examine psychological descriptions of victims of peer bullying according to their adolescent peers, based on ratings assigned to different attributes referring to physical, social and emotional characteristics. The second aim is to determine whether these descriptions corroborate perceived vulnerability and common stereotypes of victims' social (in)competence. The third aim examines how these social representations of victims are associated with sample characteristics such as country of origin, age, gender and relational status (victimization role assigned by peers) and self-reported experience of involvement in bullying situations.

\section{Method}

\section{Participants}

A total of 1237 adolescents aged 11 to 16 years old $(\underline{\mathrm{M}}=13.3$ years) were involved in this study. They were drawn from 35 classrooms in fourteen public and private schools of Elementary and Secondary Education in the cities of Granada (Spain) and Braga (Portugal). A balance of representation was maintained for students' year in school, as well as across urban and suburban schools from the two cities. Both cities are mid-size university towns, known for their fast socioeconomic and cultural development in the last decade. Besides location, school selection took into account size and educational stages offered at each school, pursuing uniform criteria according to the age, grade and educational stage that students attended in the two countries. The participants came from low, middle and middlehigh family backgrounds. The overall goals of the study, the questionnaires and the application procedures were described in initial interviews with school staff. Parental consent was requested with a written slip, included along with an informational letter addressed to the families. Teacher and student consent was requested verbally and researchers emphasized that voluntary participation was a personal choice. 
Table 1: Participant distribution according to country, sex and age $(\mathrm{N}=1237)$.

\begin{tabular}{lll}
\hline Variables & Levels & $\underline{\mathrm{N}}$ \\
\hline Country & Spain & 842 \\
& Portugal & 395 \\
& Male & 631 \\
Sex & Female & 606 \\
& $11-12$ & 278 \\
& & \\
Age groups & $13-14$ & 514 \\
& & \\
& $15-16$ & 445 \\
\hline
\end{tabular}

\section{Instruments}

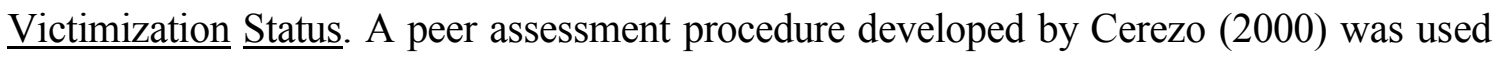
to identify which students were assigned to the different statuses. This questionnaire gathers information on preferred and non-preferred friendship choices, self-perceptions of mutual choices and rejections, plus six items to nominate up to three individuals in the classroom who fit the behavioural description of aggressors and victims. These six items comprise: who bosses, who whines and is afraid, who teases and hits others, who gets picked on by others, who is envied by others, who are the smartest ones. In two supplementary sections, five additional items request information on frequency, type, location of bullying, perceived severity of bullying and safety at school. In the present sample, $7.3 \%$ of the participants were identified as victims, $8.3 \%$ as aggressors, $82 \%$ as bystanders and $0.6 \%$ as bully-victims. In total, $5.2 \%$ of the participants state that they were bullied very often or always, $5.3 \%$ were aggressors, $52 \%$ identified themselves as pro-victim and $8 \%$ as pro-aggressors.

Procedure 
Data was collected through completion of a self-report assessment - the SCAN-Bullying Quest (Almeida \& Caurcel, 2005) - consisting of a narrative description, ratings of participants' expectations, attitudes and feelings regarding a peer bullying story, further exploring the victim's and the aggressor's experience as well as the participants' self-experience, whether they projected themselves into the victim, aggressor or bystander roles in the story.

The SCAN-Bullying Quest was designed after the Scripted-Cartoon Narrative of Peer Bullying (Almeida et al., 2001; Del Barrio et al., 2003). The original narrative assessment consists of a scripted-cartoon story and a semi-structured, open-ended interview through which participants' representations regarding bullying and the victim's and the aggressor's experience were elicited.

The questionnaire was created simultaneously in Portuguese and Spanish languages (an English version was recently presented at the PREVnet conference, Ottawa, May 2006) and was administered in each country during the last two months of the school year, between May and June, allowing for better interpersonal knowledge among classmates. Along with the questionnaire, a separate slip was handed to each student depicting the scripted-cartoon story.
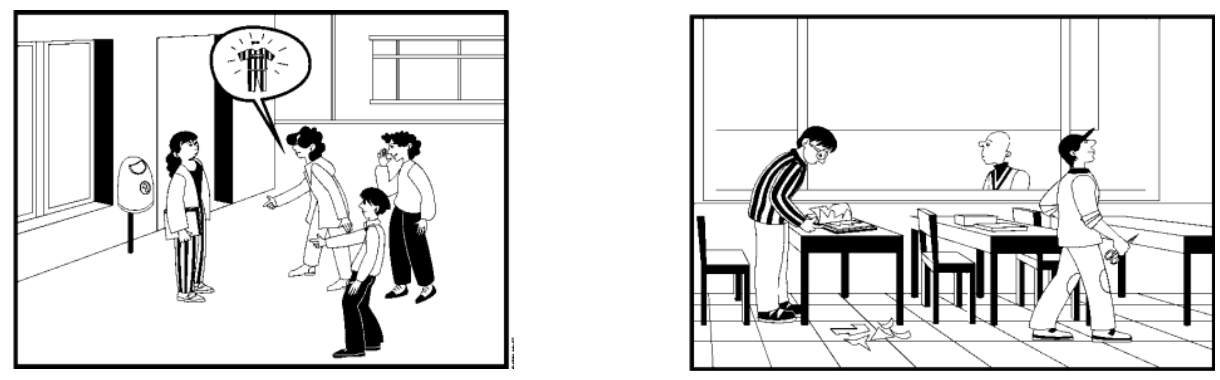

Figure 1. Examples of feminine and masculine vignettes taken from the SCAN-Bullying.

According to the two gendered versions of the bullying cartoon-narrative, masculine and feminine versions of the questionnaires were presented, each portraying a group of students (i.e., predominantly male or female) involved in different bully-victim interactions: physical and relational, direct and indirect. At the beginning, to get the students acquainted with length, scale format and questioning, the researchers read through some examples calling attention to the sections of the questionnaire, specifically clarifying wording and encouraging individuals to express any doubts. The assessment starts with a storytelling task and proceeds with examining 
attitudes, emotions, and expectations concerning the victim, the aggressors and the bystanders. Through a series of scales designed to cover these different aspects/themes, the corresponding measures resulted from the coded responses to rating scales and closed questions interspersed among a total of 36 items.

In the current study, the data report on the adolescents' descriptions of victim attributes based on a list of 14 bipolar adjectives (e.g. friendly/unfriendly; funny/boring; cool/tacky). For this particular item, a semantic differential scale (Osgood, Suci \& Tannenbaum, 1957) was used, in accordance with previous stated opinions that this type of scale is recommended for assessing the subjective meaning of a concept to the respondent; thus providing a kind of attitude scale associated with the underlying dimensions (Robson, 1993). Used purposely for exploring the victim's attributes, each adjective pair is scored on a 1-5 scale, with point 1 corresponding to the negative pole and point 5 to the positive one or, as normally associated in common sense, to a less sociable and a more sociable orientation, respectively.

\section{Results}

Data were analysed using SPSS version 13. Average ratings were computed (see Table 2) for the 14 adjective pairs and the mean scores suggest that respondents adopt a differential standpoint, with the exception of a neutral mean score in the 3 adjective pairs: "Boring/Funny"; "Tacky/Cool” and "Weak/Brave". 
Table 2. Mean and standard deviation scores for the victim profile $(N=1230)$.

\begin{tabular}{|c|c|c|}
\hline Variables & Mean & SD \\
\hline Boring vs. Funny & 2.52 & 1.372 \\
\hline Cold vs. Sensitive & 4.34 & 1.278 \\
\hline Mean vs. Kind & 4.41 & 1.240 \\
\hline Cheater vs. Straight & 4.25 & 1.268 \\
\hline Unfriendly vs. Friendly & 3.81 & 1.455 \\
\hline Tacky vs. Cool & 2.65 & 1.495 \\
\hline Weak vs. Brave & 2.15 & 1.453 \\
\hline Shy vs. Outgoing & 1.60 & 1.263 \\
\hline Sissy vs. Strong & 1.86 & 1.337 \\
\hline Dumb vs. Smart & 3.79 & 1.482 \\
\hline Arrogant vs. Humble & 4.40 & 1.160 \\
\hline Troublemaker vs Quiet & 4.59 & 1.096 \\
\hline Defiant vs. Compliant & 4.62 & 1.027 \\
\hline Bad Person vs. Good Person & 4.53 & 1.084 \\
\hline
\end{tabular}

A complementary analysis of percentage distribution for each pair of adjectives shows that the participants describe the victim through a large range of sociable attributes, considering that he or she is 'Compliant' (86.4\%), 'Quiet' (86.3\%) and a 'Good person' $(82.3 \%)$. Along with these characteristics, consensus is also found for 'Kind' $(79.2 \%)$, 'Sensitive' (75.6\%), 'Humble' (75.5\%) and 'Sincere' (71.1\%), findings that align in favour of an empathic characterization of the victim. At the opposite pole and pointing to a less sociable perception, there is a consensus of participants' opinions regarding shyness $(79.6 \%)$ and weakness $(67.2 \%)$ of victims. Compared with the last two mentioned, percentage scores for attributes like 'Sissy' (56.7\%), 'Boring' (38.6\%) and 'Tacky' (38.2\%) are less 
indicative, pointing to either a lack of consensus or a midpoint opinion less characteristic of the attribute classification.

Overall, participants' scorings reflect generalised descriptions of victims of bullying considered in the literature and, undoubtedly, the evaluative process is somewhat revealing of adolescents' common justifications for peer bullying.

\begin{tabular}{|c|c|c|c|}
\hline $\begin{array}{c}\text { Low ratings } \\
\text { Pole }\end{array}$ & \multicolumn{2}{|c|}{ Victim Profile } & $\begin{array}{l}\text { High ratings } \\
\text { Pole }\end{array}$ \\
\hline Tacky & \multirow{14}{*}{ 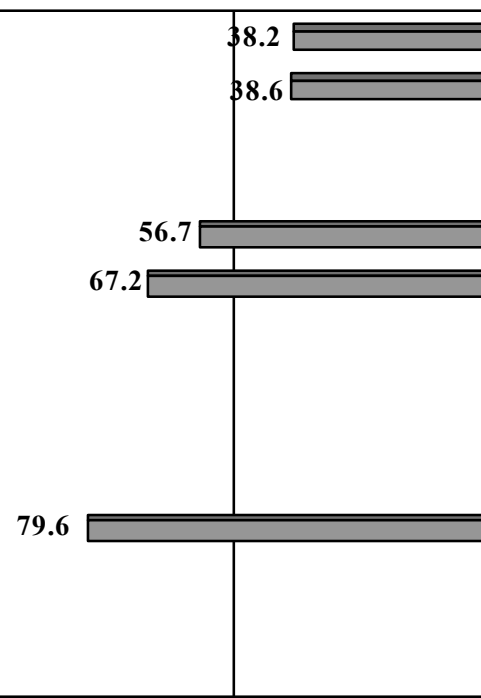 } & \multirow{7}{*}{$\begin{array}{l}54.8 \\
55.3\end{array}$} & Cool \\
\hline Boring & & & Funny \\
\hline Unfriendly & & & Friendly \\
\hline Dumb & & & Smart \\
\hline Sissy & & & Brave \\
\hline Weak & & & Strong \\
\hline Cheater & & & Straight \\
\hline Arrogant & & 76.5 & Humble \\
\hline Cold & & 76.6 & Sensitive \\
\hline Mean & & 79.2 & Kind \\
\hline Shy & & & Outgoing \\
\hline Bad person & & $\mathbf{7 8 2 . 3}$ & Good person \\
\hline Troublemaker & & D 86.3 & Quiet \\
\hline Defiant & & 86.4 & Compliant \\
\hline
\end{tabular}

Figure 2. Percentage distribution according to the bipolar adjectives in the victim profile $(\mathrm{N}=1230)$

As a step further, after the preliminary descriptive analysis, a factor analysis was carried out to examine the relationships of the different adjective pairs and link them to the underlying dimensions. Scores subjected to factor analysis consisted of the ratings transformed into a three point scale (values 2 and 4 of the original scale were transformed into 1 and 5, respectively) to reduce score dispersion.

A principal component analysis was conducted to determine the number of major dimensions characterizing the data. A rotated varimax transformation and the slope of eigenvalues suggested that two main factors were presented, with the first two principal components $(\mathrm{KMO}=0.865)$, explaining $49 \%$ of the total variance. 
The first factor aggregates 9 components and corresponds to the adjectives on the receiving pole with high ratings (ratings 5), forming a dimension that is in favour of a sociable and more positive characterization of victims. The remaining five components correspond to the adjectives receiving lower scores, loading on a second factor that is identified with a dimension that reflects a less socially competent, more vulnerable and somewhat negative stereotyped perception of victims. Internal consistency, as measured by Cronbach alpha, was 0.83 for the first factor and 0.71 for the second factor. Item correlations are presented in Table 3.

Table 3. Rotated two-factor structure of the victim profile $(\mathrm{N}=1230)$

\begin{tabular}{lcc}
\hline \multicolumn{1}{c}{ Factor } & Eigenvalues & Alpha Cronbach \\
\hline 1. Sociable description & & 0.802 \\
Good Person & 0.643 & 0.788 \\
Quiet & 0.635 & 0.778 \\
Compliant & 0.608 & 0.702 \\
Humble & 0.493 & 0.685 \\
Straight & 0.474 & 0.682 \\
Kind & 0.466 & 0.540 \\
Sensitive & 0.299 & 0.492 \\
Smart & 0.352 & 0.466 \\
Friendly & 0.403 & \\
2. Stereotype description & & 0.719 \\
Sissy & 0.518 & 0.709 \\
Weak & 0.537 & 0.660 \\
Shy & 0,534 & 0.629 \\
Tacky & 0.462 & 0.624 \\
Boring & 0.417 & \\
\hline
\end{tabular}

In order to explore whether there were significant differences according to independent variables, several univariate analyses were computed. Table 4 presents descriptives for Country. The current study began with no a priori expectations about differences related to 
cultural or geographical location. However, as the inter-group means indicate, the Spanish adolescents tend to display a more sociable profile of the victims $(\mathrm{t}=-2.497, \mathrm{p}<.05)$. Concomitantly, the Portuguese participants perceive the victims more negatively and accentuate their vulnerability $(\mathrm{t}=4.726, \mathrm{p}<.001)$.

Table 4. Descriptives of victim characterization according to Country.

\begin{tabular}{llllll}
\hline \multirow{2}{*}{ Factors } & $\begin{array}{l}\text { Independent } \\
\text { variable } \\
\text { Country }\end{array}$ & $\underline{\mathrm{N}}$ & Mean & $\mathrm{t}$ & Sig. \\
& Portugal & 391 & 38.0793 & & \\
\multirow{3}{*}{$\begin{array}{l}\text { 1. Sociable description } \\
\text { of the victim }\end{array}$} & $\begin{array}{l}\text { Spain } \\
\text { Total }\end{array}$ & 839 & 39.1907 & -2.497 & .013 \\
\hline \multirow{2}{*}{$\begin{array}{l}\text { 2. Stereotyped } \\
\text { description of the victim }\end{array}$} & Portugal & 391 & 11.6974 & & \\
& Spain & 839 & 10.3381 & 4.736 & .000 \\
& Total & 1230 & 10.7691 & & \\
\hline
\end{tabular}

Independent sample t-test revealed statistically significant differences in the victim's characterization based on gender (Table 5). The differences are suggestive of two descriptive patterns, which are consistent with traditional gender stereotypes. Adolescent girls showed a more prosocial and empathic attitude towards victims, being more positive and less negative in their characterization $(\mathrm{t}=-3.887, \mathrm{p}<.01)$. On the contrary, boys reflect a more negative and stereotyped image of the victims $(\mathrm{t}=-6.520, \mathrm{p}<.01)$.

Table 5. Descriptives of victim characterization according to gender

\begin{tabular}{|c|c|c|c|c|c|}
\hline Factors & $\begin{array}{l}\text { Independent } \\
\text { variable } \\
\text { Sex }\end{array}$ & $\mathrm{N}$ & Mean & $\mathrm{t}$ & Sig. \\
\hline \multirow{3}{*}{$\begin{array}{l}\text { 1. Sociable description } \\
\text { of the victim }\end{array}$} & Boys & 628 & 38.6545 & \multirow{3}{*}{-3.887} & \multirow{3}{*}{.000} \\
\hline & Girls & 602 & 39.6545 & & \\
\hline & Total & 1230 & 39.1545 & & \\
\hline \multirow{3}{*}{$\begin{array}{l}\text { 2. Stereotyped } \\
\text { description of the victim }\end{array}$} & Boys & 628 & 9.9219 & \multirow{3}{*}{-6.520} & \multirow{3}{*}{.000} \\
\hline & Girls & 602 & 11.6501 & & \\
\hline & Total & 1230 & 10,7895 & & \\
\hline
\end{tabular}

The univariate analysis for the three age groups yielded a significant age effect only for the second dimension identified with a stereotyped image of the victim $(\mathrm{F}=12.053$, $\mathrm{p}<.01)$. The pattern envisions an accentuation of the stereotype as adolescents grow older, particularly from 13-year-olds onwards. 
Table 6. Descriptives of victim characterization according to age.

\begin{tabular}{lllllll}
\hline \multirow{2}{*}{ Factors } & $\begin{array}{l}\text { Independent } \\
\text { variable }\end{array}$ & $\mathrm{N}$ & Mean & SD & F & \multirow{2}{*}{ Sig. } \\
& Age & & & & & \\
\cline { 1 - 5 } 1. Sociable description & 11 a 12 & 276 & 38.95 & 7.15 & & \\
of the victim & 13 a 14 & 511 & 39.26 & 7.04 & 2.177 & .114 \\
& 15 a 16 & 443 & 38.28 & 7.62 & & \\
\cline { 1 - 5 } 2. Stereotyped & Total & 1230 & 38.84 & 7.28 & & \\
description of the victim 12 & 276 & 11.84 & 5.14 & & \\
& 13 a 14 & 511 & 10.79 & 4.66 & 12.053 & .000 \\
& 15 a 16 & 443 & 10.08 & 4.46 & & \\
\hline & Total & 1230 & 10.77 & 4.73 & & \\
\hline
\end{tabular}

Of particular interest to the current study is examining how victim characterization is related to victimization status or role assigned through peer ratings. Based on previous findings, eighty-nine students were identified as victims, one-hundred and nine were aggressors and the remaining who were classified in neither of these statuses were grouped under the category of observers. Analyses of variance were performed to identify whether victim characterization shows differences related to status assigned (Table 7).

Table 7. Descriptives of victim characterization according to victimization status.

\begin{tabular}{lllllll}
\hline \multirow{2}{*}{ Factors } & $\begin{array}{l}\text { Independent } \\
\text { variable } \\
\text { Status }\end{array}$ & N & Mean & SD & F & Sig. \\
& Victim & 89 & 39.72 & 6.61 & & \\
1. Sociable description & Aggressor & 103 & 36.55 & 8.42 & 5.767 & .000 \\
of the victim & Observer & 1009 & 39.11 & 7.07 & & \\
& Total & 1201 & 38.46 & 7.37 & & \\
\hline \multirow{2}{*}{ 2. Stereotyped } & Victim & 89 & 11.43 & 5.41 & & \\
description of the victim & Aggressor & 103 & 9.09 & 4.45 & 4.769 & .001 \\
& Observer & 1009 & 10.93 & 4.67 & & \\
\hline
\end{tabular}

For this particular question, we expected to link stereotyped and vulnerability perceptions of victims to the aggressors' descriptions. In addition, in line with social appropriateness often reported in the literature (Smith, 2004), we expected to find a generally favourable image of the victims among observers. Besides, it was also plausible to predict that adolescents assigned to the victim status would describe the victim in a more empathic 
and sociable mode, as a reflection of activated complicity with the experience of the story's protagonist. Nonetheless, it was more hazardous to predict whether this form of complicity would be reflected in the second factor. If indeed stereotypes are construed upon a social representation of the perceived vulnerability of victims, it can be expected that victims will perceive themselves as vulnerable and less socially valued, sustaining the weight of this interpersonal negative categorization.

As seen in Table 7, these hypotheses were partially confirmed. Role assignment is related to the above predictions, with an exception for the last hypothesized relationship, since victim's status does not hold a positive relationship with the stereotyped description. For their own sake, victims do not share a negative belief about themselves. As predicted, ratings of adolescents in the aggressors' group reflect a less positive image of the victims and an amplified idea of their negative attributes, as shown in the low ratings assigned to the second factor $(\mathrm{F}=5.767, \mathrm{p}<.01 ; \mathrm{F}=4.679, \mathrm{p}<.01)$. This is presumably a reflection of their nonemotional involvement, or else a justification to reinforce anticipated aggressive behaviours toward the victim group.

Finally, observers' descriptions are similar to the victims' and at the same time are more neutral, as normally expected.

Further exploring the hypothesized contributions of representational and behavioural experience to the victims' perceptions, additional analyses were carried out to investigate how self-reported experience as a victim, an aggressor, a pro-victim or a pro-aggressor is related to positive and negative dimensions of the victim's profile.

Regarding self-reported experience as a victim, results of the univariate analysis of variance (see Table 8) showed that participants with zero or few experiences as a victim hold a more stigmatized perception of this group. A contrasting attitude was found among selfreported victims whose descriptions were indicative of less stereotyped views and, indeed, revealed a self-serving social image and a positive orientation towards their own group $(\mathrm{F}=$ 5.509, $\mathrm{p}<.01)$. By contrast, experience as an aggressor was associated with a marked negative view of the victim's vulnerabilities $(\mathrm{F}=15.719, \mathrm{p}<.01)$ as well as a less positive view of his or her sociability $(\mathrm{F}=14.055, \mathrm{p}<.01)$ (see Table 9). 
Table 8. Descriptives of victim characterization according to self-reported experience as victim.

\begin{tabular}{|c|c|c|c|c|c|c|}
\hline Factors & $\begin{array}{l}\text { Independent } \\
\text { variable } \\
\text { Self-reported } \\
\text { experience } \\
\end{array}$ & $\mathrm{N}$ & Mean & SD & $\mathrm{F}$ & Sig. \\
\hline \multirow{5}{*}{$\begin{array}{l}\text { 1. Sociable description } \\
\text { of the victim }\end{array}$} & Never & 722 & 38.58 & 7.53 & \multirow{5}{*}{.993} & \multirow{5}{*}{.395} \\
\hline & A few times & 327 & 39.40 & 6.27 & & \\
\hline & Sometimes & 115 & 38.72 & 7.76 & & \\
\hline & Very often/Always & 64 & 39.12 & 8.22 & & \\
\hline & Total & 1228 & 38.84 & 7.28 & & \\
\hline \multirow{5}{*}{$\begin{array}{l}\text { 2. Stereotyped } \\
\text { description of the } \\
\text { victim }\end{array}$} & Never & 722 & 10.57 & 4.69 & \multirow{5}{*}{5.509} & \multirow{5}{*}{.001} \\
\hline & A few times & 327 & 10.55 & 4.54 & & \\
\hline & Sometimes & 115 & 11.54 & 4.55 & & \\
\hline & Very often/Always & 64 & 12.75 & 5.87 & & \\
\hline & Total & 1228 & 10.77 & 4.73 & & \\
\hline
\end{tabular}

Table 9. Descriptives of victim characterization according to self-reported experience as aggressor.

\begin{tabular}{lllllll}
\hline \multirow{2}{*}{ Factors } & $\begin{array}{l}\text { Independent variable } \\
\text { Self-reported }\end{array}$ & N & Mean & SD & F & Sig. \\
& experience & & & & & \\
\hline \multirow{4}{*}{$\begin{array}{llllll}\text { Never Sociable description } \\
\text { of the victim }\end{array}$} & A few times & 655 & 39.44 & 7.08 & & \\
& Sometimes & 152 & 39.13 & 6.76 & & \\
& Very often/Always & 65 & 37.91 & 7.51 & 14.055 & .000 \\
& Total & 1223 & 38.61 & 9.15 & & \\
2. Stereotyped & Never & 655 & 11.59 & 4.72 & & \\
description of the & A few times & 351 & 10.01 & 4.35 & & \\
victim & Sometimes & 152 & 9.26 & 4.58 & 15.719 & .000 \\
& Very often/Always & 65 & 10.16 & 5.54 & & \\
\hline
\end{tabular}

Regarding self-reported experience as pro-victim and pro-aggressor bystanders, the analysis of variance performed showed statistically significant differences (see Table 10 and 11). Again, the results indicated that experience was directly contributing to the victim's characterization. Congruent with the tendencies described above, a more systematic helping attitude is associated with positive characterization of the victims $(\mathrm{F}=5.640, \mathrm{p}<.01)$ while the opposite effect is observed for non-involvement and a more negative description of victims' vulnerabilities $(\mathrm{F}=11.693, \mathrm{p}<.01)$. Simultaneously, less involved pro-aggressor 
bystanders hold a more favourable perception of the victims $(F=18.689, \mathrm{p}<.01)$, as compared to supportive reinforcers of bullies $(\mathrm{F}=11.989, \mathrm{p}<.01)$, who sustain the typical stereotyped image of the victim.

Table 10. Descriptives of victim characterization according to self-reported experience as provictim bystander

\begin{tabular}{lllllll}
\hline \multirow{2}{*}{ Factors } & $\begin{array}{l}\text { Independent variable } \\
\text { Self-reported }\end{array}$ & $\mathrm{N}$ & Mean & SD & F & Sig. \\
& experience & & & & & \\
\hline \multirow{3}{*}{$\begin{array}{l}\text { Never } \\
\text { description of the }\end{array}$} & A few times & 97 & 36.46 & 7.91 & & \\
victim & Sometimes & 326 & 38.75 & 6.82 & 5.640 & .001 \\
& Very often/Always & 638 & 39.45 & 7.18 & & \\
& Total & 1224 & 38.85 & 7.28 & & \\
\hline \multirow{3}{*}{ Stereotyped } & Never & 98 & 9.43 & 4.78 & & \\
description of the & A few times & 163 & 9.71 & 4.63 & & \\
victim & Sometimes & 326 & 10.31 & 4.36 & 11.693 & .000 \\
& Very often/Always & 637 & 11.49 & 4.80 & & \\
& Total & 1224 & 10.78 & 4.73 & & \\
\hline
\end{tabular}


Table 11. Descriptives of victim characterization according to self-reported experience proaggressor bystander.

\begin{tabular}{|c|c|c|c|c|c|c|}
\hline Factors & $\begin{array}{l}\text { Independent variabl } \\
\text { Self-reported } \\
\text { experience }\end{array}$ & $\mathrm{N}$ & Mean & SD & $\mathrm{F}$ & Sig. \\
\hline \multirow{5}{*}{$\begin{array}{l}\text { 1. Sociable } \\
\text { description of the } \\
\text { victim }\end{array}$} & Never & 705 & 39.91 & 6.62 & \multirow{5}{*}{18.689} & \multirow{5}{*}{.000} \\
\hline & A few times & 255 & 38.33 & 7.09 & & \\
\hline & Sometimes & 165 & 37.65 & 7.03 & & \\
\hline & Very often/ Always & 99 & 34.63 & 10.22 & & \\
\hline & Total & 1224 & 38.85 & 7.28 & & \\
\hline \multirow{5}{*}{$\begin{array}{l}\text { 2. Stereotyped } \\
\text { description of the } \\
\text { victim }\end{array}$} & Never & 705 & 11.45 & 4.69 & \multirow{5}{*}{11.989} & \multirow{5}{*}{.000} \\
\hline & A few times & 255 & 9.93 & 4.38 & & \\
\hline & Sometimes & 165 & 9.56 & 4.48 & & \\
\hline & Very often/ Always & 99 & 10.17 & 5.41 & & \\
\hline & Total & 1224 & 10.78 & 4.73 & & \\
\hline
\end{tabular}

\section{Discussion}

This study investigated perceived characteristics of victims of peer bullying in a sample of adolescents from two southern European countries. Following several international reports claiming that bullying is a worldwide phenomenon, it continues to be important to provide data from different societies and cultural backgrounds. Moreover, the present study begins by critically reflecting upon explanations of peer bullying and reclaiming the importance of examining it from a relationship perspective. Focusing upon the perceived characteristics of victimized peers, the main goal was to inspect how victim descriptions varied according to victimization status (whether aggressor, bystander or victim) and self-reported experience as participant in bullying interactions. Although this is part of a larger project investigating attitudes regarding other participant roles, for the time being we begin by setting our theoretical framework and describing first findings regarding the victim characteristics according to their nonvictimized and victimized peers.

Studying bullying in adolescence has been of particular significance to many authors. A strong argument for the attention devoted to this age period has been stressed by developmental studies on peer relationships. To put it clearly, it has been assumed that peer bullying can be especially damaging to adolescents, when failure to fit into the peer group can symbolize a failure to master a critical developmental task (Lease, McFall \& Viken, 2003). Wondering about similarities and dissimilarities with others in and out of the peer 
group typically consumes a good deal of adolescents' daily activity (Rubin et al., 1998). And indeed, to perceive oneself as possessing characteristics that others find awkward induces concerns about peer acceptance and self-adequacy which, in the case of victimized adolescents, can reinforce the aggressor's behaviour (Perry, Kusel \& Perry, 1988; Perry et al., 1990). The particular implications of the consequences of the victim's behaviour have led many authors to investigate the individual characteristics of children that are targets of their peers' aggressive acts (for a review, see Almeida, in press).

Another reason to study victims of bullying lies in the controversial opinion that victimized children can turn into aggressors by identifying with the aggressor (unconcious defence mechanism) or by transferring aggressive feelings or retaliating against more the vulnerable. Since this calls for a larger focus of study extending the individual perspective to include an interpersonal and a relational point of view, this topic will most probably benefit from a more integrative psychological paradigm. Despite the claim that victimization cannot be accounted for by victims' behavioural or nonbehavioural characteristics, the fact is that too often the victims are sanctioned (Sweeting \& West, 2001). The issue gains additional relevance in adolescence. Both self-definitional concerns of any typical adolescent, as well as the increased preoccupation regarding his or her social image ("how others see me") introduce extra risk factors for those who have antecedents of rejection or other difficulties in their peer relations. Even in the presence of different coping strategies and envisioning their adaptive outcomes, individual differences do not explain victimization histories. Victimization, whether experienced, observed or enacted is subject to socially shared situations. In this line of reasoning, perceptions of bullying and peer reputations are mutually informing and constitutive elements of experience and of representations. Enlisting different perspectives, different roles will contribute to co-construe the interpersonal experience and its meaning.

Specifically, our results are consistent with these assumptions. Although the majority of boys and girls in our sample were assigned to a bystander role and, consequently, reported that they had not experienced bullying on a regular basis, a smaller number did report to have experience as a victim and as an aggressor and were equally assigned to each role. Thus, the set of descriptions of victim characteristics reflect the social perceptions of these three subgroups. Our findings revealed the social image of a passive victim, whose perceived 
vulnerability consists mainly of a shy, fearful, fragile nature, coupled with a sensitive, compliant, quiet and humble personality. Although this characterization has traits coinciding with the public stereotype of the passive victim, it is far from being too discriminative or negative. Whereas shyness and fearful might denote that these descriptions are emphasizing an insecure and anxious socioemotional pattern, other attributes like "boring" and "tacky", or even "dumb" associated with incompetence and deviance were not strongly stressed. Besides, about $80 \%$ of the adolescents perceive the victim as a "good person" and "kind", indicating that the attitude beneath is favourable and expresses empathy towards the victim. Otherwise, this attitude aligns with an appropriate social orientation that, unless challenged, peers will continue to verbalize. This commentary should not be interpreted as a criticism, but as a widely evidenced trend. Sympathy and friendly attitudes towards the victim apparently gather high consensus but, at the same time, this ethical concern is not coupled with action. It undoubtedly is less attractive to act in support of the victims. According to Salmivalli (2001), 60 to $70 \%$ of students do nothing to stop bullying. No matter how much prevention programs encourage enlistment of victim defenders, it is important to be aware of these numbers and to be conscious about the relative ease of considering bullying an ethical and moral issue. Particularly in adolescence, challenging and promoting anti-bullying attitudes have to go beyond enrolling defenders.

Namely, reported differences with age and gender showed that the perceived vulnerability of victims is accentuated as adolescents grow older and that boys as compared to girls take a more critical attitude towards victims. These findings are not surprising in themselves, but again evoke self-definitional issues which affect a concept of "manliness". In addition, implications are also more visible for boys whenever bullying takes more overt expressions. Other findings allow us to extend our reflections about the transactional relation of interpersonal perceptions. The reported data are extremely consistent across the two conditions. Peer nominations and self-reported experience point in the same direction: peer ratings and experience as aggressor are linked to less favourable and increased vulnerability perceived in the victim descriptions, whereas bystanders and other adolescents having experienced or being peer-rated as victims held less stereotyped perceptions.

In conclusion, explanations for bullying are an ongoing challenge to research. They raise a number of controversial issues about human nature, and the function and 
manifestations of aggression in development, and they collide with a complex puzzle of educational approaches. Responses to bullying have not always been grounded in a research evidence basis.

In bullying and victimization research, for instance, the different disciplines offer an enormous set of information about "what is it", "which children are perpetrators and targets of bullying behavior", "what are its psychological and health consequences", "how can it be prevented", etc. This information generated debates which have influenced the ideas of teachers, parents, experts, and people, in turn influencing intervention programs and attitudes towards the subjects.

However, information is not enough to dismantle beliefs and attitudes which sometimes are opposed to action and resistant to change. Myths and misconceptions can have insidious effects in dealing with peer victimization issues. Sullivan (2000) examines a number of these 'long-standing truths' to discuss their underlying justifications. A rather common and particularly dangerous myth stresses that bullying is character-building, suggesting that it is the victim's fault if he or she is bullied because they should stand up for themselves. While this and other similar beliefs accentuate the vulnerability of the victims, objectivity in science is far from socially innocuous. 


\section{References}

Almeida, A. \& Caurcel, M. (2005). Questionário Scan-Bullying. Versão Portuguesa e Castelhana. [Scan-Bullying Questionnaire. Portuguese and Spanish versions.] Registo de obra na Inspecção-Geral das Actividades Culturais, Ministério da Cultura.

Almeida, A., del Barrio, C., Marques, M., Fernández, I., Gutiérrez, H. \& Cruz, J. (2001). A script-cartoon narrative of peer-bullying in children and adolescents. In M. Martínez (Ed.), Prevention and control of aggression and its impact on its victims (pp. 161168). New York: Kluwer Academic/ Plenum Publishers.

Almeida, A. (in press). Para além das tendências normativas: o que aprendemos com o estudo dos maus tratos entre pares. [Beyond normative tendencies: what we learn from the study of bullying.] Psychologica, pending publication.

Alsaker, F. D. \& Olweus, D. (1992). Stability of self-esteem in early adolescence: A cohort longitudinal study. Journal of Research on Adolescence, 2,123-145.

Baldwin, J. M. (1897). Social and ethical interpretations in mental development. New York: Macmillan.

Baldwin, J. M. (1906). Mental development in the child and the race (3rd ed.). New York: Kelley.

Boivin, M., Hymel, S. \& Hodges, E. V. E. (2001). Toward a process view of peer rejection and harassment. In J. Juvonen \& S. Graham (Eds.), Peer Harrassment in School: The Plight of the Vulnerable and Victimized (pp. 265 - 309). New York: The Guilford Press.

Bretherton, I., \& Munholland, K. A. (1999). Internal working models in attachment relationships: A construct revisited. In J. Cassidy \& P. R. Shaver (Eds.), Handbook of attachment: Theory, research, and clinical applications (pp. 89 -111). New York: Guilford.

Carlson, E., A. Sroufe, L. A. \& Egeland, B. (2004). The Construction of Experience: A Longitudinal Study of Representation and Behavior. Child Development, 75, 1, 66 83.

Cerezo, F. (2000). Bull-S. Test de evaluación de la agresividad entre escolares. [Bull-S. Test for evaluating aggressiveness among schoolchildren.] Madrid: Albor-Cohs.

Del Barrio, C., Almeida, A., van der Meulen, K., Barrios, A. \& Gutiérrez, H. (2003). Representaciones acerca del maltrato entre iguales, atribuciones emocionales y 
percepción de estrategias de cambio a partir de un instrumento narrativo: SCANBullying. [Representations about bullying, emotional attributions and change strategies, based on a narrative instrument: SCAN- Bullying.] Infancia $y$ Aprendizaje, 26, 63-78.

DeRosier, M. E., Cillessen, A. H. N., Coie, J. D., \& Dodge, K. A. (1994). Group context and children's aggressive behavior. Child Development, 65, 1068-1079.

Hartup, W. W. (1983). Peer relations. In E. M. Hetherington (Ed.) \& P. H. Mussen (Series Ed.), Handbook of child psychology: Vol. 4. Socialization, personality, and social development (pp. 103-196). New York: Wiley.

Hartup, W.W. (1996). The company they keep: friendships and their developmental significance. Child Development, 67, 1-13.

Hymel, S., Wagner, E. \& Butler, L. J. (1990). Reputational bias: View from the peer group. In S. R. Asher \& J. D. Coie (Eds.), Peer rejection in childhood (pp. 156-186).New York: Cambridge University Press.

Hymel, S., Woody, E., Bowker, A. (1993). Social withdrawal in childhood: considering the child's perspective. In K. H .Rubin \& J. B. Asendorpf (Eds.), Social withdrawal, inhibition, and shyness in childhood (pp.237-264). Hillsdale, NJ.: Lawrence Erlbaum.

Kochenderfer-Ladd, B. (2003). Identification of Aggressive and Asocial Victims and the Stability of Their Peer Victimization. Merrill-Palmer Quarterly, 49, 4, 401

Laursen, B. (2005). Dyadic and group perspectives on close relationships. International Journal of Behavioral Development, 29, 2, 97-100.

Lease, A. M., McFall, R.M. \& Viken, R.J. (2003). Distance From Peers in the Group's Perceived Organizational Structure: Relation to Individual Characteristics. Journal of Early Adolescence, 23, 2, 194-217

Mead, G. H. (1934). Mind, self, and society from the standpoint of a social behaviorist. Chicago: University of Chicago Press.

Mellor, A. (1999). Scotland . In Smith, P., Morita, Y., Junger-Tas, J. Olweus, D. Catalano, R. \& Slee, P. (Eds) The Nature of School Bullying: A cross national perspective (pp.91-111). London: Routledge.

Moscovici, S. (1981). On social representation. In J. P. Forgas (Ed.), Social Cognition. London: Academic Press.

Naylor, P. Granizo, L., Tantam, D. \& Deurzen, E. (2005). Bullying of secondary school pupils with Asperger syndrome/high functioning autism (AS/HFA): a pilot study. 
Poster presented at the XII European Conference on Developmental Psychology, Tenerife, August, 24-28.

Olweus, D. (1978). Aggression in the Schools: Bullies and whipping boys. Washington DC: Hemisphere.

Olweus, D. (1993). Victimization by peers: antecedents and long-term outcomes. In K. Rubin \& J. Asendorpf (Eds.), Social withdrawal, inhibition, and shyness in childhood (pp. 315-342). Hilldsdale, NJ: Erlbaum.

Ortega y Gasset, J. (1983). Obras Completas, Vol. 1-12. [Complete Works, Vol. 1-12]. Madrid: Alianza Editorial.

Osgood, C. E., Suci, C. J. \& Tannenbaum, P. H. (1957). The measurement of meaning. Urbana, Ill.: University of Illinois Press.

Pepler, D. J. \& Craig, W.(2006). Introduction to Prevnet Pillars. Keynote oral presentation at PREVNet First International Conference, Ottawa, Ontario, May, 25 - 26.

Pepler, D. J., Craig, W. \& O’Connell, P. (1996). Understanding bullying and victimization from a dynamic systems perspective. In A. Slater \& d. Muir (Eds.), Developmental Psychology: An advanced reader (pp. 441-451). London: Blackwell.

Perry, D., Williard, J. \& Perry, L. (1990). Peers' perceptions of the consequences that victimized children provide aggressors. Child Development, 61, 1310-25.

Perry, D.G., Kusel, S. J. \& Perry, L.C. (1988). Victims of peer aggression, Developmental Psychology, 24, 807-814.

Rivers, I. (2001). The bullying of sexual minorities at school: Its nature and long-term correlates. Educational and Child Psychology, 18, 32-46.

Robinson, W. P. (1996). Social groups \& identities. Developing the legacy of Henry Tafel. Oxford: Butterworth-Heinemann.

Rubin, K. D., Bukowski, W. M. \& Parker, J. G. (1998). Peer interactions, relationships and groups. In W. Damon \& N. Eisenberg (Eds.), Handbook of child psychology: Vol.3, Social and emotional development (pp. 619-700). Wiley, New York,.

Salmivalli, C. (1998). Not only bullies and victims. Participation in harassment in school classes: some social and personality factors. Humaniora, Annales Universitatis Turkuensis, 7-37.

Salmivalli, C. (2001). Group view on victimization. Empirical findings and their implications. In J. Juvonen \& S. Graham (Eds.), Peer harassment in school. The plight of the vulnerable and victimized (398-420). Guilford: New York. 
Salmivalli, C., Lagerspetz, K., Björkqvist, K., Österman, K. \& Kaukiainen, A. (1996). Bullying as a group process: Participant roles and their relations to social status within the group. Aggressive Behavior, 22, 1-15.

Siann, G., Callaghan, M., Glissov, P., Lockhart, R. And Rawson, L. (1994). Who gets bullied? The effect of school, gender and ethnic group, Educational Research, 36, $123-34$.

Smith, P. (2004). Bullying: Recent Developments. Child and Adolescent Mental Health, 9, 3, 98-103.

Sullivan, H. S. (1953). The interpersonal theory of psychiatry. New York: Norton.

Sullivan, K., (2000). The anti-bullying handbook. Oxford University Press.

Sweeting, H. \& West, P. (2001). Being different: correlates of the experience of teasing and bullying at age 11, Research Papers in Education 16, 3, 225 - 246.

Tajfel, H. (1978). European Monographs in Social Psychology: Differentiation between social groups. Vol. 14. London: Academic Press.

Tattum, D. (1989). Violence and aggression in schools. In Tattum, D. \& Lane, D. (Eds) Bullying in Schools. Stoke on Trent: Trentham.

Tattum, D. (1997). A whole-school response: from crisis management to prevention, Irish Journal of Psychology, 18, 221 - 32.

Vaillancourt, T., McDougall, P., Hymel, S. \& Welch, E. (2001). A comprehensive profile of peer victimized adolescent and their oppressors. Poster presented at the X European conference on Developmental Psychology, August, 22-26. 
[Página en blanco por razones de paginación] 